temperature control has been installed in rooms used for this work. The testing of trichloroethylene inhalers intended for use by registered midwives has been facilitated by the use of the new gas refractometer referred to previously. Two prototypes have been approved, and about 110 inhalers have been tested. 'Trouble-shooting', the theme of an interesting exhibit, stressed the assistance given by the Test House to enable manufacturers to overcome their production difficulties and to improve the quality and accuracy of their output.

E. I. Brimelow

1 National Physical Laboratory. Report for the Xear 1955 (London: H.M.S.O., 1956)

${ }^{2}$ Allen, N. P., Hopkins, B. E., and McLennan, J. E., Proc. Roy. Soc. A, 234, 221 (1956)

${ }^{3}$ Dadson, R. S., Nature, 176, 188 (1955).

4 Essen, L., and Parry, J. V. L., Nature, 177, 744 (1956).

5 "Wage Accounting by Electronic Computer" (London: H.M.S.O., 1956).

\title{
OBITUARIES
}

\section{Prof. Carl Ramsauer}

Carl Ramsauer, who died in Berlin on December 24, 1955, was an outstanding character as well as an outstanding physicist. As a young man, he made his way by his toughness and purpose. Born on February 6, 1879, in Osterburg, a little place in Oldenburg where his father was the Lutheran parson, in his early twenties he occupied a diversity of positions, including those of schoolmaster and assistant in the torpedo laboratory at $\mathrm{Kiel}$, at which University he took his doctorate with an interesting and original thesis on the mechanism of ricochet from water. He was twenty-eight when Lenard, who had been professor at Kiel, enabled him to take up an academic career by appointing him to a post in the Physics Institute at Heidelberg. Here he worked, except for the war period, during which he was an artillery officer, until 1921, when he was appointed professor of physics at the Technische Hochschule at Danzig. With Lenard he carried out a series of significant researches on the ionization produced by ultra-violet light; but the work that brought his name into prominence was his discovery, in 1921, that slow electrons pass much more easily than swifter ones through the atoms of the rare gases, the so-called Ramsauer effect. In this connexion he introduced the term Wirkungsquerschnitt (effective cross-section), which has been so widely used.

At Danzig, Ramsauer proceeded to transform the small and comparatively unimportant department into a first-class institute for teaching and research in physics. He was by inclination and training an outstanding teacher, taking the greatest pains and pleasure to devise effective lecture experiments and to make clear the fundamentals of the subject. The research school, which was occupied mainly, but by no means exclusively, with the passage of electrons through matter, was known for the precision and clarity of its work. By 1928 his reputation was such that when the Allgemeine Elektricitätsgesellschaft decided to found a research institute, Ramsauer was appointed to direct it. His gifts as an organizer and controller of research found full expression in this extremely responsible post. Under him work proceeded not only in physical, but also in chemical, electrotechnical, metallurgical and other departments of the great institute. He installed 'technicalphysical workshops', which were of great value. $\mathrm{He}$ continued his personal research on effective atomic and molecular cross-sections, and the work which he carried out with Kollath on the scattering of protons is classical. In 1931 he became joint editor of the Zeitschrift für technische Physik, and many other responsibilities of this nature accrued to him.

During the Second World War, Ramsauer was elected president of the Deutsche Physikalische
Gesellschaft, a very difficult position at that time. With characteristic courage he spoke out against the many abuses and shameful personalities which were ruining German physics, his letter, sent in 1942, to Rust, then Minister for Education, being particularly uncompromising. It had no result ; but if Ramsauer had been a less valuable and less respected man it might have been fatal for him.

After the War, Ramsauer occupied himself with reorganizing the teaching of physics at the Technische Hochschule at Charlottenburg, a task for which his gifts and experience particularly fitted him. In 1953 he published a remarkable little book dealing with the history of certain fundamental experiments in physics. He did not give up his post until he reached the age of seventy-five, and died shortly after his resignation.

Ramsauer was a quite exceptional personality. $\mathrm{He}$ disliked any parade of sentiment, but he was a staunch friend and a man of firm principles, who never truckled to those in power. He was a most entertaining talker, with a strong and sometimes biting sense of humour, to which he gave epigrammatic expression. For example, of a certain somewhat undistinguished physicist who had a double name-let us call him Wolf-Braun-he said, "GaussWeber were two men, Mittag-Leffler was one man, Wolf-Braun was nobody". He had a close acquaintance with German university folk-lore, including the legends of Bonifacius Kiesewetter, and a great knowledge of German literature in general, including many byways. He will long be remembered by all who had to do with him, and especially by the few still living who knew him at Heidelberg.

$$
\text { E. N. Da C. Andrade }
$$

\section{Sir John Stirling-Maxwell, Bart., K.T.}

Sir John Stirling-Maxwell died on May 30 at the age of eighty-nine at his home, Pollok House, famous for its lovely gardens, near Glasgow. He succeeded his father at the age of eleven, and went to Eton and then on to Trinity College, Cambridge. He was Conservative member of Parliament for the College Division of Glasgow between 1895 and 1906, when he lost the seat. It was then that he gave his time to his real hobby. Sir John may be termed one of the early modern pioneers of forestry, then called arboriculture in Scotland and England, in the latter part of the past century and the early years of the present. He studied the subject intensively in many European countries and made use of the knowledge so acquired on his own estate, and was always ready with advice or suggestions to friends.

In his own practice, after failures to establish sitka spruce plantations on his estate at Corrour, and his 
greatly loved lodge there, by the usual methods of level surface planting on peat soils, he introduced the method he had seen in Belgium of mound planting, in which the plants are placed in holes in the turves cut out in making the drains. He had immediate success at Corrour; and when, a few years later, the Forestry Commission began its work in the country, it followed Sir John on peat soils, afterwards greatly elaborating other methods. Sir John, whose whole heart was in forestry, was one of the first Commissioners, and his appointment as chairman of the Forestry Commission in 1929 was warmly hailed by foresters and all who knew of his work and his enthusiasm, and his departure at the end of his term of office at the end of 1932 was equally regretted. His quiet geniality, understanding and common sense were greatly appreciated and loved.

Sir John's life was devoted to public service. He had a great affection for art and acted in many public positions in this respect: as trustee of the Royal Fine Art Commission for Scotland, chairman of the Ancient Monuments Board of Scotland and as a trustee of the Scots National Galleries. He was an original member of the Board of Trustees of the Wallace Collections appointed to administer the bequest in 1897, and he served contiriuously on the Board, being its chairman for the past twenty-five years.

Sir John did a great deal to encourage the beginnings of forestry in Great Britain, and his name will remain enshrined in the annals of forestry.

E. P. Stebbinct

\section{NEWS and VIEWS}

Experimental Philosophy at Oxford: The Right Hon. Viscount Cherwell, P.C., C.H., F.R.S.

For a man who shuns publicity, Lord Cherwell has been much in the news lately. In the recent Birthday Honours List he was made a Viscount and very shortly afterwards he announced his impending resignation from the Dr. Lee's chair of experimental philosophy at Oxford. F. A. Lindemann (now Viscount Cherwell) was educated in England and Germany and took his Ph.D. degree under Nernst at the University of Berlin in 1913. During his period in Germany he published, in conjunction with Nernst, a series of papers on "Studies of Specific Heats at Low Temperatures", and also proposed modifications in the Planck-Einstein formula for specific heats of solids based on the quantum theory and extended it to gases. Later, he published a book entitled "The Physical Significance of the Quantum Theory". During the First World War, Lindemann served as an experimental pilot and research scientist at the Royal Aircraft Establishment, Farnborough. It was during this period that he played a very large part in the successful solution of the spinning aircraft problem. In 1919, Lindemann was appointed professor of experimental philosophy at Oxford, so that he has held this chair for thirty-seven years. During this period he has built up the Clarendon Laboratory and initiated many important researches to such effect that to-day the Clarendon Laboratory is among the best equipped and staffed laboratories in the world for both low temperature and nuclear research work.

In pre-war years Lindemann formed a very firm friendship with Winston Churchill, and when at the outbreak of the War the latter was appointed First Lord of the Admiralty, Lindemann joined him in the capacity of personal scientific-adviser. Later, when Churchill became Prime Minister, he moved with him to Downing Street. He was raised to the Peerage as Lord Cherwell in 1941 and in 1942 became Paymaster General and a member of the Cabinet. His duties were primarily scientific and statistical, and he was charged with the responsibility of keeping the Prime Minister acquainted with all the scientific problems and developments. which affected the war effort. 'This he did largely by the use of his characteristically simple but illuminating methods of presenting information. In addition to this, he also accompanied the Prime Minister to the historic Quebes and
Potsdam Conferences.

Cherwell again became Paymaster General in 1951 and served in a similar capacity. His particular interests at this period were in the atomic energy field, and he was one of the main protagonists of the plan afterwards adopted for the removal of the Atomic Energy programme from the Civil Service. After his return to Oxford in 1953 he continued to serve as a member of the new Atomic Energy Authority. Cherwell is a man of strong opinions which he has not hesitated to advance. Many people have disagreed with him, but few will deny that he has had an important influence on our time.

Sir Francis Simon, C.B.E., F.R.S.

SiR Francis Simon, professor of thermodynamics in the University, has been appointed to succeed Viscount Cherwell. The Clarendon Laboratory will thus have as its new head a man who has a worldwide reputation for his achievements in all branches of low-temperature physics. Sir Francis, like Lord Cherwell, began his scientific career under Nernst, and it is not surprising that much of his earlier work was connected with the Nernst heat theorem. Indeed, the fact that this theorem is now generally recognized as the third fundamental law of thermodynamics is largely due to his work. During this period in Germany he also devised the small-scale cryogenic techniques, in particular the expansion method for liquefying helium, which made it possible to conduot low-temperature work even in laboratories with only quite modest facilities. On leaving Germany in 1933 , he went to the Clarendon Laboratory at the invitation of Prof. Lindemann and became reader and later professor of thermodynamics. Under him the lowtemperature department of the Clarendon Laboratory has grown to be one of the leading cryogenic laboratories of the world. His many interests have included the properties of liquid helium, magnetic cooling, lowtemperature specific heats (in particular, the study of internal transitions), nuclear orientation, thermal conductivities and the properties of solids and fluids at high pressures and low temperatures. During the War, Prof. Simon played an important part in the British Atomic Energy project. He was one of the first to see the feasibility of a diffusion plant for the separation of the uranium isotopes on an industrial scale and he had a large group working under him on this project. Since the War he has also turned his attention to many questions of scientific policy, and 